\title{
DETERMINATION OF POLLEN VIABILITY AND GERMINATION RATIOS IN MERSIN ECOLOGY OF SOME EARLY APRICOT
}

\author{
Mehmet Yaman ${ }^{1}$, Sibel Turan ${ }^{2, *}$ \\ ${ }^{1}$ Erciyes University, Faculty of Agriculture, Department of Horticulture, Turkey \\ ${ }^{2}$ Erciyes University, Faculty of Agriculture, Department of Agricultural Biotechnology, Turkey
}

\begin{abstract}
Turkey is the leading country in the production of world apricots (Prunus armeniaca). In the country, apricots are usually grown for drying and fresh consumption, and apricots are also used for different purposes. This study was carried out to determine pollen viability and germination status in some foreign apricot varieties grown in Mut district of Mersin province, which has an important place in early ripening apricot production in Turkey. Pollen viability and germination ratios were determined by TTC and 1\% agar 10\% method in Mogador, Mikado, Pricia, Flopria apricot varieties. In terms of pollen values, the best result in terms of viable pollen is from the Mikado with $77.02 \%$ and Mogador varieties with $78.61 \%$, while the Pricia variety with $44.09 \%$ in semi-viable pollen provides the most result, while Flopria and Pricia varieties produce the highest values in dead pollen results. In the germination tests, pollen germination rates were medium level in Flopria, Mogador and Mikado varieties the pollen germination rate of the Pricia variety is only $8.96 \%$. The results obtained will be a guide in new orchard establishment and breeding studies.
\end{abstract}

Keywords: Apricot, breeding, pollen germination, pollen viability, TTC

\section{INTRODUCTION}

Turkey ranks first among the leading countries in the world in apricot production. This production value is 846.606 tons according to 2019 year's statistics (FAO, 2019). Apricots are usually produced as drying and fresh consume in Turkey (Ercisli, 2009). While the province of Malatya is leading in drying production, Mersin has a say in fresh consume production thanks to the early varieties brought to the country with low cooling requirements.

Late spring frosts are among the factors affecting the production of apricot (Kaya et al., 2018). Like other stone fruit types, apricots can be affected by frost from time to time since it blooms early in the spring. In addition, problems arising from pollination and fertilization are among the factors that affect fruit yield in apricot. Apricot has a hermaphrodite flower structure (Asma, 2011), and as with most fruits, the parts of the flower must develop fully and healthy in order to obtain economic products (Abac1 and Asma, 2014). However, due to the incompatibility seen in apricot, there are great problems at the point of pollination and fertilization.

In order to make apricot cultivation, the fertilization biology and s allele structures of the variety or cultivars to be used in the new orchard to be established should be well known. In addition, it is important to determine the pollen viability and germination rates that affect the pollination and fertilization success. Pollen viability and germination are affected by many factors such as ecology, 
annual maintenance work, especially genetic structure (Brittain et al., 2014; Klein et al., 2015; Yaman and Uzun, 2020).

This study was carried out in order to determine pollen viability and germination status in some foreign apricot varieties grown in Mut district of Mersin province, which has an important place in early ripening apricot production in Turkey.

\section{MATERIALS AND METHODS}

\section{Material}

The pollens of the apricot varieties used in the study were obtained from Mogador, Mikado, Pricia and Flopria varieties grown in Mut, Mersin province in 2021 year. The varieties used in the study are 3-4 years old and the flowers that have reached the stage of balloon for pollen extraction were taken from different sides of the tree and branches of different heights. The anthers were separated from the flowers with a forceps. It was kept overnight at room temperature for pollen bursting.

\section{Method}

\section{Pollen Viability Test}

2,3,5, Tripyhenyl Tetrazolium Chlorid (TTC) was used to determine the pollen viability of different cultivars. Norton's method (1966) was used in the preparation of the TTC solution.

Flower powders of the varieties were sprinkled on the TTC solution dropped on the slide with a watercolor brush and a lamella was placed on it. 3 sets were prepared for each variety and counts were made under a light microscope in 3 different regions in each set. During the count, red colored pollens were considered as viable, pink colored ones as semi-viable and colorless (not dyed) as dead (Abacı and Asma 2014).

\section{Pollen Germination Test}

The medium containing $1 \%$ agar $+10 \%$ sucrose was used to determine the pollen germination rates. Counts were made in 3 petri dishes for each variety and in 3 different regions for each petri dish. Before counting, the pollens were sprinkled with a watercolor brush and kept at 23-25 C degrees for 24 hours. Similar to the pollen viability test, observations were made under a light microscope.

\section{Data Analysis}

Experimental data were subjected to statistical analyses with the aid of software SPSS 15.0 (IBM Company, USA) and significant means were compared with Duncan's multiple range test at $P<.05$ significance level and the values of the varieties are presented as mean \pm standard deviation (SD).

\section{RESULTS AND DISCUSSIONS}

Pollen viability of genotypes used in the study significant differences in levels were observed (Table 1). Obtained from TTC test on pollen belonging to genotypes \% of differences between living and nonliving rates 95 confidence was determined to be statistically significant $(\mathrm{P}<0.5)$. The highest viability rate was observed in the Mikado with $77.02 \%$ and Mogador varieties with $78.61 \%$, and the lowest value was observed in Pricia apricot genotype with 44.09\%.

Pollen viability levels, environment varieties in terms of conditions and fertilization biology compatibility between fruit trees the most important affecting fruit holding capacity are factors Kelen and Demitaş, 2003; Dantas et al., 2005). Misırlı et al. (2004) by TTC test on five apricot varieties according to the 2001 data of the research in the pollen viability analysis, the pollen viability rate is $75.93 \%$ (Hasanbey) and they determined that it ranged between 52.66 (Hacihaliloğlu). Asma (2008) found pollen viability values between 77.5\% (Canino) and 41.5\% 


\section{Current Trends in Natural Sciences}

Vol. 10, Issue 19, pp. 166-169, 2021

https://doi.org/10.47068/ctns.2021.v10i19.021

Current Trends in Natural Sciences (on-line)

ISSN: 2284-953X

ISSN-L: 2284-9521

Current Trends in Natural Sciences (CD-Rom)

ISSN: 2284-9521

ISSN-L: 2284-9521

(Roxana) in his study on eight apricot genotypes. Bircan and Karg1 (2013) found that pollen viability values varied between $89.06 \%$ (Aurora) and $52.39 \%$ (Pisana) in their study with thirteen apricot varieties, and pollen viability levels varied according to the variety and years and feeding. They reported that the location of the tree and the flower in the tree may change depending on the branch load and many other factors.

Table 1. Percentages of viable, semi-viable and dead pollen in apricot varieties used in the study

\begin{tabular}{llll}
\hline Varieties & $\begin{array}{l}\text { Viable } \\
(\boldsymbol{\%})\end{array}$ & $\begin{array}{l}\text { Semi-viable } \\
(\boldsymbol{\%})\end{array}$ & $\begin{array}{l}\text { Dead } \\
(\boldsymbol{\%})\end{array}$ \\
\hline Flopria & $52.96 \pm 13.60 \mathrm{~b}$ & $29.16 \pm 10.16 \mathrm{ab}$ & $17.86 \pm 8.55 \mathrm{a}$ \\
Mogador & $78.61 \pm 2.68 \mathrm{a}$ & $19.25 \pm 1.31 \mathrm{~b}$ & $2.12 \pm 1.37 \mathrm{~b}$ \\
Pricia & $34.64 \pm 6.09 \mathrm{c}$ & $44.09 \pm 8.83 \mathrm{a}$ & $21.27 \pm 8.05 \mathrm{a}$ \\
Mikado & $77.02 \pm 10.36 \mathrm{a}$ & $17.01 \pm 8.73 \mathrm{~b}$ & $5.96 \pm 2.45 \mathrm{~b}$ \\
\hline Mean & $\mathbf{6 0 . 8 1} \pm \mathbf{2 0 . 5 6}$ & $\mathbf{2 7 . 3 8} \pm \mathbf{1 3 . 0 9}$ & $\mathbf{1 1 . 8 0 \pm 9 . 7 8}$ \\
\hline
\end{tabular}
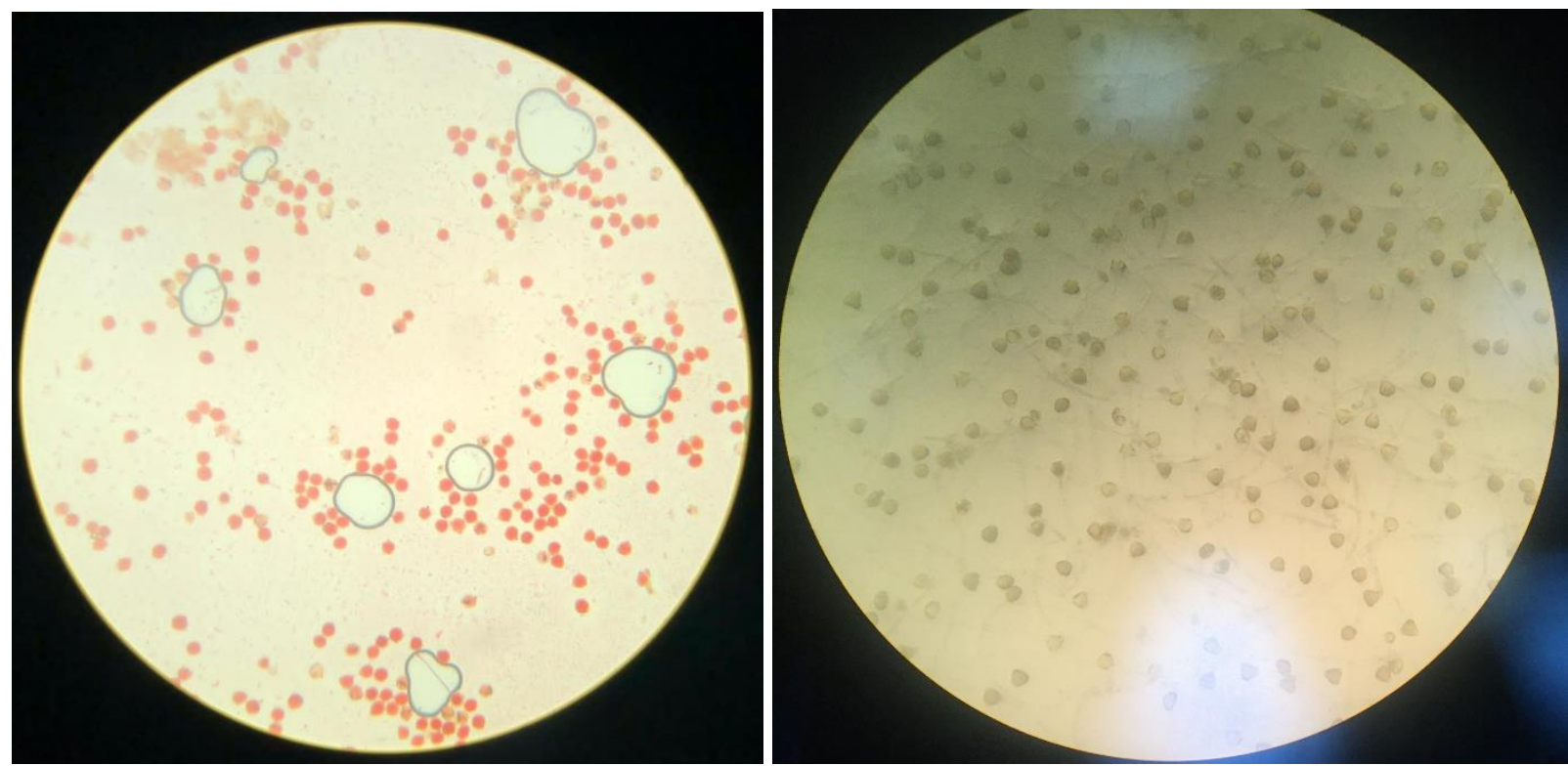

Figure 1. Pollen viability and germination in the mikado apricot variety

Table 2. Percentages of pollen germinated and non-germinated in the apricot varieties used in the study.

\begin{tabular}{lll} 
Varieties & \multicolumn{1}{c}{$\begin{array}{c}\text { Germinated } \\
(\boldsymbol{\%})\end{array}$} & \multicolumn{1}{c}{$\begin{array}{c}\text { Non-germinated } \\
(\boldsymbol{\%})\end{array}$} \\
\hline Flopria & $59.63 \pm 4.93 \mathrm{a}$ & $40.36 \pm 4.93 \mathrm{~b}$ \\
Mogador & $46.93 \pm 11.85 \mathrm{a}$ & $53.06 \pm 11.85 \mathrm{~b}$ \\
Pricia & $8.96 \pm 6.47 \mathrm{~b}$ & $91.03 \pm 6.47 \mathrm{a}$ \\
Mikado & $41.23 \pm 15.73 \mathrm{a}$ & $58.76 \pm 15.73 \mathrm{~b}$ \\
\hline Mean & $\mathbf{3 9 . 1 9} \pm \mathbf{2 1 . 5 2}$ & $\mathbf{6 0 . 8 0} \pm \mathbf{2 1 . 5 2}$ \\
\hline
\end{tabular}


Pollen germination power of apricot varieties is required to be at least $25 \%$. Conditions that arise depending on the genetic structure, nutrition and environmental conditions affect the germination power (Asma, 2011). In this study, the highest germination rate was obtained in Flopria variety with $59.63 \%$, while the lowest germination rate was obtained in Pricia variety with $8.96 \%$ (Table 2).

Paydaş et al. (2001), in their study on sixty-two natural apricot genotypes, stated that the pollens of these genotypes worked on agar-petri media containing $0.6 \%$ agar +15 sucrose. They found that the germination strength varied between $79.19 \%$ (31 K03) and 34.66\% (Ablugoz). Bircan and Karg1 (2013) found that pollen germination rates in 1\% agar +15 sucrose environment varied between 49.99\% (Ninfa) and 3.63\% (Bulida) in their study with thirteen apricot varieties, and the germination ability of pollen was determined according to germination environments, varieties and years. They state that as it changes, it can change depending on the climatic conditions, the nutrition of the tree and many other factors.

\section{CONCLUSIONS}

As a result, low pollen germination rate and short pollen tube are factors affecting fruit setting rate and tree productivity. This is undesirable by both the breeder and the producer. For this reason, it is necessary to know the viability of the plant pollens that will be produced or used as sire in breeding programs.

\section{REFERENCES}

Abaci, Z., Asma, B. (2014). Investigation of pollen longevity and germination status and pollen tube lengths in hybrid genotypes. Anadolu Tarım Bilimleri Dergisi, 29(1), 12-19.

Asma, B. M. (2011). Her Yönüyle Kayısı, Uyum Ajans [Apricot in All Aspects, Compliance Agency], İstanbul.

Asma, B.M. (2008). Determination of polen viability, germination ratios and morphology of eight apricot genotypes. African Journal of Biotechnology. 7 (23), 4269-4273.

Bircan, M., Kargı, S.P. (2013). Aurora Kayısı Çeşidinin Döllenme Biyolojisi Üzerine Araştırmalar.[Studies on Fertilization Biology of Aurora Apricot Varieties] Alatarım, 12 (2), 10-19.

Brittain, C., Kremen, C., Garber, G., Klein, A.M. (2014). Pollination and plant resources change the nutritional quality of almonds for human health. PLoS One, 9:e90082.

Dantas, A. C. De M., Peixoto, M. L., Nodari, R. O., Guerra, M. P. (2005). Germination of pollen and the development of pollen tubes in apple (Malus spp.). Revista Brasielira Fruticultura, 27(3): 356-359.

Ercisli, S. (2009). Apricot culture in Turkey. Sci. Res. Essays, 4(8), 715-719.

Kaya, O., Kose, C., Gecim, T. (2018). An exothermic process involved in the late spring frost injury to flower buds of some apricot cultivars (Prunus armenica L.). Scientia Horticulturae, 241, 322-328.

Kelen, M., Demitaş, I. (2003). Pollen viability, germination capability and pollen production level of some grape varieties (Vitis vinifera L.). Acta Physiologies Plantarum, 25: 229-233.

Klein, A.M., Hendrix, S.D., Clough, Y., Scofield, A., Kremen, A. (2015). Interacting effects of pollination, water and nutrients on fruit tree performance. Plant Biology, 17:201-208.

Mısırlı, A., Gülcan, R., Sağlam, H., Ataol Ölmez, H. (2004). Önemli Kurutmalık Kayısı Çeşitlerinin Döllenme Biyolojisi Üzerine Araştırmalar [Studies on Fertilization Biology of Important Dried Apricot Varieties], TÜBITTAK Project Final Report (Proje No: TARP-2573-1). http://uvt.ulakbim. gov.tr (Erişim Tarihi:03.04.2014).

Norton, J.D. (1966). Testing of plum pollen viability with tetrazolium salts Proc. Amer. Soc. Hort. Sci. $89: 132$ 134

Paydaş, S., Eti, S., Derin, K., Yılmaz, K.U. (2001). İn vitro investigations on polen quality, production and selfincompatibility of some apricot varieties in Malatya- Turkey. XIIth İnternational symposium on apricot culture and decline. Sept. 10-14, France.

Yaman, M., Uzun, A. (2020). Evaluation of Superior Hybrid Individuals with Intra and Interspecific Hybridization Breeding in Apricot. International Journal of Fruit Science, 20(sup3), S2045-S2055. 